\author{
Contatos \\ Victor Andrade de Melo \\ Programa de Pós-Graduação em \\ História Comparada - PPGHC \\ Largo de São Francisco de Paula, n. 1, sala 311 \\ 2005 1-070 - Rio de Janeiro - Rio de Janeiro \\ victor.a.melo@uol.com.br \\ Eduardo Souza Gomes \\ Rua Dr. Paulo Alves, 126 - apto. 1004 \\ 24210-445 - Niterói - Rio de Janeiro \\ eduardogomes.historia@gmail.com
}

\section{OS BRITÂNICOS E OS CLUBES DE CRICKET NA SÃO PAULO DO SÉCULO XIX} (ANOS 1870-1890)

\section{(1) Victor Andrade Melo**}

Universidade Federal do Rio de Janeiro Rio de Janeiro - Rio de Janeiro - Brasil

\section{(1) Eduardo Souza Gomes ${ }^{* * *}$}

Universidade Federal do Rio de Janeiro Rio de Janeiro - Rio de Janeiro - Brasil

\title{
Resumo
}

Assim como ocorreu em muitos países, no Brasil, as primeiras iniciativas esportivas foram protagonizadas por britânicos. Em São Paulo, isso se tornou visível a partir da década de 1870. Considerando a relevância dessas situações no que tange à conformação de uma cultura citadina, o objetivo deste artigo é discutir as experiências dos clubes de críquete fundados na capital paulistana nas últimas três décadas do século XIX, com especial interesse pelas dinâmicas de sociabilidade. Para alcance do intuito utilizamos como fontes periódicos publicados na cidade e no Rio de Janeiro. Esperamos entender como essas iniciativas tiveram relação com o desenvolvimento de outros esportes, entre os quais o futebol. Tratou-se de um processo de trânsito cultural que nos permite lançar um olhar sobre nossa formação societária.

\section{Palavras-chave}

História de São Paulo - história do esporte - críquete - futebol - trânsito cultural.

* A pesquisa que deu origem a este artigo recebeu apoio da Capes (bolsa de doutorado), Faperj (Programa Cientista de Nosso Estado) e CNPq (Bolsa de Produtividade de Pesquisa). Ambos os autores participaram de todas as etapas de produção deste artigo.

** Pós-doutor em História pela Universidade Federal Fluminense. Doutor em Educação Física pela Universidade Gama Filho. Mestre em Educação Física pela Universidade Estadual de Campinas e licenciado em Educação Física pela Universidade do Estado do Rio de Janeiro.

${ }^{* * *}$ Doutorando pelo Instituto de História da Universidade Federal do Rio de Janeiro - UFRJ. Mestre pela mesma instituição. Licenciado em História pela Universidade do Estado do Rio de Janeiro. 
Contacts

Victor Andrade de Melo

Programa de Pós-Graduação em História Comparada - PPGHC

Largo de São Francisco de Paula, n. 1, sala 311 20051-070 - Rio de Janeiro - Rio de Janeiro victor.a.melo@uol.com.br

Eduardo Souza Gomes Rua Dr. Paulo Alves, 126 - apto. 1004 2421 0-445 - Niterói - Rio de Janeiro eduardogomes.historia@gmail.com

\section{- Victor Andrade Melo}

Universidade Federal do Rio de Janeiro Rio de Janeiro - Rio de Janeiro - Brasil

\section{Eduardo Souza Gomes}

Universidade Federal do Rio de Janeiro Rio de Janeiro - Rio de Janeiro - Brasil

\begin{abstract}
As in many countries, in Brazil, British carried out the first sports initiatives. In São Paulo, this became visible from the 1870s. Considering the relevance of these situations in relation to the conformation of a city culture, the purpose of this article is to discuss the experiences of cricket clubs based in São Paulo during the last three decades of the 19th century, with a special interest in the dynamics of sociability. To reach our goal we use as sources periodicals published in the city and in Rio de Janeiro. We hope to understand how these initiatives were related to the development of other sports, including football. It is a process of cultural transit that allows us to look at our society formation.
\end{abstract}

\title{
Keywords
}

São Paulo history - sport history - cricket - football - cultural transit. 


\section{Introdução}

No cenário mundial, há algumas regularidades no que tange à estruturação dos esportes, desdobramento de importantes mudanças que impactaram o cotidiano citadino. Em geral, articulada com a melhor conformação de um mercado de entretenimentos, relacionou-se a uma maior ocupação da cena pública, a melhorias da infraestrutura urbana (especialmente no tocante às possibilidades de locomoção), a uma certa vitalidade econômica (que possibilita o usufruto de "supérfluos") e ao acesso a novas formas de pensar a vida em sociedade, em muitas ocasiões fruto da adesão ao ideário e imaginário modernos, processo potencializado por trânsitos culturais, pela maior difusão de comportamentos e modos de viver que chegavam de outros países considerados mais civilizados (MELO, 2010). ${ }^{1}$

No caso da difusão mundial do esporte, há que se ter em conta o importante papel desempenhado pelos britânicos. Essa "invenção inglesa" se espraiou no século XIX a bordo do protagonismo do Reino Unido no que tange ao forjar de ideias e realizações ligadas ao progresso. Por meio de seus navios e de sua presença em muitos países, anglófonos estiveram entre os pioneiros na organização de iniciativas esportivas, tanto aquelas de caráter mais elitista como o críquete quanto as mais populares como o futebol (MANGAN, 1986). ${ }^{2}$ Nesse processo, as influências lidaram com as peculiaridades históricas e culturais locais, mas de certa maneira apresentaram um novo conjunto de técnicas e princípios que foram sendo amplamente adotados.

Há que se ter em conta que, no século XIX, em muitas cidades do mundo, os britânicos desempenharam um papel notável atuando nas indústrias, instituições financeiras, obras públicas, firmas de comércio e empresas ferroviárias. No Brasil, inclusive em São Paulo, foi claramente perceptível tal presença e intervenção. ${ }^{3}$ Estiveram envolvidos, por exemplo, nas pioneiras inicia-

\footnotetext{
1 MELO, Victor Andrade de. Esporte e lazer: conceito - uma introdução histórica. Rio de Janeiro: Apicuri/ Faperj, 2010.

2 MANGAN, James A. The games ethic and imperialism: aspects of the diffusion of an ideal. Nova York: Viking, 1986.

3 BRUNO, Ernani Silva. História e tradições da cidade de São Paulo: burgo de estudantes (1828-1872). Rio de Janeiro: José Olímpio, 1954a; Idem. História e tradições da cidade de São Paulo: metrópole do café (1872-1918). Rio de Janeiro: José Olímpio, 1954b; SAES, Flávio Azevedo Marques. As ferrovias de São Paulo, 1870-1940. São Paulo: Hucitec, 1981; TOLEDO, Roberto Pompeu de. A capital da solidão: uma história de São Paulo das origens a 1900. Rio de Janeiro: Objetiva, 2003; SZMRECSÁNYI, Tamás. História econômica da cidade de São Paulo. Rio de Janeiro: Globo, 2004; SILVA, Gustavo Pereira da. A dinâmica do enriquecimento paulista no século XIX: das origens à diversificação do capital
} 
Victor Andrade Melo e Eduardo Souza Gomes Os britânicos e os clubes de cricketna São Paulo do século XIX (anos 1870-1890)

tivas férreas protagonizadas por Mauá, cujo intuito era construir uma linha entre São Paulo e Santos. ${ }^{4}$ Na verdade, já na primeira metade daquela centúria, alguns projetos não executados contaram com a participação de anglófonos, como os que atuavam nas firmas Samuel Philips $\mathcal{E}$ Cia e Platt $\mathcal{E}$ Reid. ${ }^{5}$

Deve-se destacar que o aumento de seu protagonismo se deu num contexto em que "cidades e indústrias se impuseram no cenário nacional, não só como novos fenômenos econômicos e sociais, mas como possibilidades reais e dominantes". ${ }^{6}$ O que houve em São Paulo, processo mais perceptível a partir dos anos 1890, foi bem representativo do que ocorreu em outras localidades do Brasil. Paulatinamente, deixou-se para trás a imagem pacata da capital paulistana:

Prensada em meio à prosperidade crescente da lavoura cafeeira, de um lado, e às tensões derivadas da crise final da escravidão no país, de outro, a antiga cidade de barro dos viajantes - o velho burgo de estudantes da faculdade de direito do largo de São Francisco - se transformava, de forma acelerada, na "metrópole do café".

Nesse cenário, percebe-se maior adesão a ideias de civilização e progresso, algo que, articulado com mudanças no âmbito da economia e da política, estimulou a progressiva estruturação de um mercado de entrete-

da família Lacerda Franco. Estudos Econômicos, vol. 45, n. 2, São Paulo, 2015, p. 347-376. ISSN 1980-5357. Disponível em: 〈http://www.scielo.br/pdf/ee/v45n2/0101-4161-ee-45-02-0347.pdf〉. Acesso em: 5 abr. 2019. DOI: http://dx.doi.org/10.1590/0101-4161201545244gps.

4 A São Paulo Railway inaugurou o primeiro trecho no final dos anos 1860. Na década seguinte, seria inaugurado o tramo da Estrada de Ferro D. Pedro II (futura Central do Brasil) que completaria a ligação da capital paulista à Corte. Cf. GRANDI, Guilherme. Estado e capital ferroviário em São Paulo: a Companhia Paulista de Estradas de Ferro entre 1930 e 1961. Tese de doutorado, FFLCH/ USP, São Paulo, 2013.

5 MONTEIRO, Arlete Assumpção. Os imigrantes ao longo dos trilhos da The São Paulo Railway. Raízes, n. 19, São Caetano do Sul, ano X, jul. 1999, p. 37-43. Ver também: GUIMARÃES, Carlos Gabriel. A presença inglesa nas finanças e no comércio no Brasil imperial: os casos da Sociedade Bancária Mauá, MacGregor E Cia. (1854-1866) e da firma inglesa Samuel Phillips E Cia. (1808-1840). São Paulo: Alameda Editorial, 2012.

6 SCHWARCZ, Lília Moritz. As marcas do período. In: Idem (coord.). História do Brasil nação (18082010), vol. 3: A abertura para o mundo (1889-1930). Rio de Janeiro: Objetiva, 2012. p. 19-34. p. 31.

7 SCHWARCZ, Lília Moritz. População e sociedade. In: Idem (coord.). História do Brasil nação (18082010), vol. 3: A abertura para o mundo (1889-1930). Rio de Janeiro: Objetiva, 2012b, p. 35-84, p. 45. Para mais informações ver FRANCO, Gustavo H. B. \& LAGO, Luiz Aranha Corrêa do. O processo econômico/ a economia da Primeira República, 1889-1930. In: SCHWARCZ, Lilia Moritz (coord.). História do Brasil nação (1808-2010), vol. 3: A abertura para o mundo (1889-1930). Rio de Janeiro: Objetiva, 2012, p. 173-238. 
Victor Andrade Melo e Eduardo Souza Gomes Os britânicos e os clubes de cricketna São Paulo do século XIX (anos 1870-1890)

nimentos do qual fazia parte, entre outros, o teatro, ${ }^{8}$ a dança, ${ }^{9}$ as touradas ${ }^{10}$ a patinação ${ }^{11}$ e os esportes, tema central de nosso estudo, prática cuja conformação foi bastante tributária das iniciativas de oriundos do Reino Unido.

Como era usual nas cidades pelo mundo em que se instalavam, em São Paulo os britânicos procuraram organizar iniciativas ligadas a suas referências culturais, entre as quais podemos destacar a prática de esportes, inclusive daquele que por eles é considerado um de seus traços mais característicos, o críquete. ${ }^{12}$ Dedicados à modalidade, criaram clubes, uma de suas estratégias prediletas de sociabilidade, ${ }^{13}$ nos quais cultuavam seus valores e formas de comportamento público marcado por certo comedimento e aversão ao exibicionismo. ${ }^{14}$ Bem traduziu a valorização desse esporte um cronista de um periódico destinado à colônia britânica: “Onde há críquete, há ingleses dignos do nome, fortes, musculosos e aptos. Onde não há críquete, existem britânicos desperdiçados em terras estrangeiras".15

"Nada confunde mais um estrangeiro do que o jogo de críquete", afirmou outro cronista do mesmo periódico. ${ }^{16}$ De fato, para muitos se tratava

\footnotetext{
8 AMARAL, Antônio Barreto do. História dos velhos teatros de São Paulo: da Casa da Ópera à inauguração do Teatro Municipal. São Paulo: Governo do Estado de São Paulo, 1979; MAGALDI, Sábato \& VARGAS, Maria Thereza. Cem anos de teatro em São Paulo. São Paulo: Senac, 2000.

9 MELO, Victor Andrade de E SANTOS, Flávia da Cruz. Escola de virtudes: a dança na São Paulo do século XIX (décadas de 1830-1860). Educação e Realidade, vol. 43, n. 3, Porto Alegre, 2018, p. 1031-1054. ISSN 2175-6236. Disponível em:<https://seer.ufrgs.br/educacaoerealidade/article/ view/74388>. Acesso em: 5 abr. 2019. DOI: http://dx.doi.org/10.1590/2175-623674388.

${ }^{10}$ SANTOS, Flávia da Cruz \& MELO, Victor Andrade de. Entre o rural e o urbano: as touradas na São Paulo do século XIX (1877-1889). Revista do IHGB, n. 463, Rio de Janeiro, abr./jun. 2014, p. 39-69. ISSN 0101-4366. Disponível em:<https://ihgb.org.br/revista-eletronica/artigos-463/ item/108159-entre-o-rural-e-o-urbano-as-touradas-na-sao-paulo-do-seculo-xix-1877-1889. html >. Acesso em: 5 abr. 2019.

${ }^{11}$ MELO, Victor Andrade de \& SANTOS, Flávia da Cruz. Deslizando rumo ao progresso: a patinação em São Paulo (1877-1912). Movimento, vol. 23, n. 1, Porto Alegre, mar. 2017, p. 171-184. ISSN 1982-8918. Disponível em: <https://seer.ufrgs.br/Movimento/article/view/61350>. Acesso em: 5 abr. 2019. DOI: https://doi.org/10.22456/1982-8918.61350.

${ }^{12}$ Burke e Pallares-Burke discutem a importância dos esportes, inclusive do críquete, para os britânicos. Cf. BURKE, Peter \& PALLARES-BURKE, Maria Lúcia Garcia. Os ingleses. São Paulo: Contexto, 2016. Para mais informações sobre a prática da modalidade na Grã-Bretanha ver MANGAN, James A. Athleticism in the Victorian and Edwardian public school. Cambridge: University Press, 1981; HOLT, Richard. Sport and the British: a modern history. Nova York: Oxford University Press, 1989.

${ }^{13}$ Para um debate sobre a importância dos clubes para os britânicos ver SOARES, Luiz Carlos. A Albion revisitada. Rio de Janeiro: 7 Letras/Faperj, 2007.

${ }^{14}$ BURKE, Peter \& PALLARES-BURKE, Maria Lúcia Garcia. Os ingleses, op. cit., 2016.

${ }^{15}$ The Rio News, 6 de dezembro de 1898, p. 5.

${ }^{16}$ The Rio News, 16 de maio de 1899, p. 4.
} 
Victor Andrade Melo e Eduardo Souza Gomes Os britânicos e os clubes de cricketna São Paulo do século XIX (anos 1870-1890)

de um esporte um tanto confuso. Joga-se com onze jogadores de cada lado, utilizando-se bolas e tacos, em um campo (gramado, na maioria das vezes) sem dimensões fixas e, normalmente, em formato oval. O objetivo é eliminar 10 wickets do adversário, bem como alcançar o maior número possível de corridas. É cercado de rituais que os britânicos cultuam com devoção. Ainda que pouco praticado no Brasil dos dias atuais, trata-se de uma das modalidades esportivas coletivas mais difundidas no mundo, junto com o futebol e o rúgbi. ${ }^{17}$

Considerando que essa valorização das agremiações e dos esportes tratase de um tema relevante para discutir as estratégias de sociabilidade adotadas pela colônia britânica, ${ }^{18}$ bem como a conformação de uma cultura citadina na capital paulistana, este estudo tem por objetivo discutir as experiências dos clubes de críquete criados em São Paulo nas três últimas décadas do século XIX. Como fizeram parte de um movimento articulado, abordaremos também as iniciativas promovidas em Campinas e, principalmente, Santos, cidades que tinham anglófonos estabelecidos e passaram também por processos de mudanças ligadas à adesão ao ideário e imaginário da modernidade.

O recorte temporal considerou tanto o pioneirismo das experiências com o críquete entabuladas em São Paulo - estiveram entre as primeiras iniciativas esportivas da cidade - quanto sua articulação com outros aspectos que compunham um período tão importante da história da capital paulistana - imigração, urbanização, desenvolvimento econômico, trânsito cultural. ${ }^{19}$

Para alcance do objetivo, utilizamos como fontes periódicos publicados no período em tela, especialmente três jornais. ${ }^{20} \mathrm{O}$ Correio Paulistano, lançado em meados dos anos 1850, foi um dos mais influentes da capital, atuan-

\footnotetext{
${ }_{17}$ Para mais informações ver <https://escola.britannica.com.br/levels/fundamental/article/ cr\%C3\%ADquete/481075>. Acesso em: 1 set. 2018.

${ }^{18}$ Neste artigo, denominaremos de colônia britânica e britânicos não somente os que, vivendo no Brasil, nasceram no Reino Unido, mas todos os que possuíam laços familiares com essa nação, inclusive os descendentes natos em território brasileiro ou outros países.

${ }^{19}$ Trânsito cultural não é por nós compreendido como um processo linear e acrítico de assimilação. Consideramos que, ainda que existam desníveis de poder e influência, por motivos diversos e com graus distintos, trata-se de uma postura ativa de releitura, adaptação, apropriação, que acaba por gerar apreensões peculiares. Para um debate sobre tal olhar ver CANCLINI, Néstor García. Culturas híbridas: estratégias para entrar e sair da modernidade. São Paulo: Edusp, 1997.

${ }^{20}$ Para trato do material, procuramos seguir o sugerido por LUCA, Tânia Regina de. História dos, nos e por meio dos periódicos. In: PINSKY, Carla Bassanezi (org.). Fontes históricas. São Paulo: Ed. Contexto, 2005, p. 111-153.
} 
Victor Andrade Melo e Eduardo Souza Gomes Os britânicos e os clubes de cricketna São Paulo do século XIX (anos 1870-1890)

do como porta-voz dos interesses da oligarquia local. ${ }^{21}$ O Diário de São Paulo (1865-1878), politicamente bem ativo, destacava-se pelos seus pontos de vista conservadores. ${ }^{22}$ Já $A$ Província de São Paulo, que veio às bancas em 1875 e segue ativo até os dias de hoje (a partir de 1889, passou a se chamar $O$ Estado de S. Paulo), estava mais relacionado aos liberais e republicanos, tornando-se, na transição de séculos, o mais importante do Estado (MARTINS \& LUCA, 2006). ${ }^{23}$

Deve-se ter em conta que, mesmo que adotassem posicionamentos distintos em vários temas, manifestos inclusive nas suas preocupações com a regulação da cena urbana, os três periódicos de alguma forma elogiaram os divertimentos públicos, notadamente os esportes, entendidos como sinais de que progredia e se civilizava a capital paulistana. ${ }^{24}$

Além disso, foram consultados periódicos editados em inglês que tinham como público-alvo os britânicos espalhados pelo Brasil. Ainda que publicados no Rio de Janeiro, concedendo maior atenção ao que na Corte/ Distrito Federal ocorria, tais veículos informaram e se dirigiram também aos que estavam estabelecidos em outras cidades, notadamente São Paulo, Campinas, Santos, Salvador e Recife.

O The Anglo-Brazilian Times: Political, Litterary and Comercial foi publicado entre 1865 e 1884. ${ }^{25}$ O The Rio News circulou entre 1874 e 1901. ${ }^{26}$ Já o The Brazilian Review foi editado entre 1898 e 1914. Mesmo que esse último tenha dedicado mais atenção às questões econômicas, assim como os outros, informava algo do cotidiano dos britânicos, inclusive as atividades de seus clubes, entre

\footnotetext{
${ }^{21}$ THALASSA, Ângela. O Correio Paulistano: o primeiro diário de São Paulo e a cobertura da Semana de Arte Moderna - o jornal que não ladra, não cacareja e não morde. Dissertação de mestrado em Comunicação e Semiótica, Pontifícia Universidade Católica de São Paulo, São Paulo, 2007.

22 DIAS, Márcia Hilsdorf. O Diário de São Paulo como fonte. In: VIDAL, Diana Gonçalves \& SOUZA, Maria Cecília Cortez Christiano de (org.). A memória e a sombra - a escola brasileira entre o Império e a República. Belo Horizonte: Autêntica, 1999, p. 21-31.

${ }^{23}$ MARTINS, Ana Luiza \& LUCA, Tania Regina de. Imprensa e cidade. São Paulo: Editora Unesp, 2006.

${ }^{24}$ MELO, Victor Andrade de E SANTOS, Flávia da Cruz. Deslizando rumo ao progresso..., op. cit., 2017.

${ }^{25}$ Para mais informações ver ARAÚJO NETO, Miguel Alexandre de. Great Britain, the Paraguayan War and free immigration in Brazil, 1862-1875. Irish Migration Studies in Latin America, vol. 4, n. 3, Bakersfield, jul. 2006. ISSN 1661-6065. Disponível em: <http://www.irlandeses.org/0607_ 115to132.pdf $>$. Acesso em: 5 abr. 2019.

${ }^{26}$ Para mais informações ver ROCHA, Antônio Penalves. The Rio News de A. J. Lamoureux: um jornal abolicionista carioca de um norte-americano. Projeto História, n. 35, São Paulo, dez. 2007, p. 141-159. ISSN 0102-4442. Disponível em: <https://revistas.pucsp.br/index.php/revph/article/ view/2210>. Acesso em: 5 abr. 2019.
} 
Victor Andrade Melo e Eduardo Souza Gomes Os britânicos e os clubes de cricketna São Paulo do século XIX (anos 1870-1890)

os quais os esportivos. O tema, a propósito, era valorizado pelos editores dos três periódicos. ${ }^{27}$

Vale assinalar que se os britânicos, a princípio, mantiveram certa distância de outros grupos da sociedade paulistana. No decorrer do tempo se percebem mudanças nessa postura, notadamente a partir dos anos 1890, quando se observa a gestação de mais espaços de interface, nos quais alguns de seus costumes puderam ser conhecidos por diferentes estratos da população. ${ }^{28}$

Na mesma medida, deve-se considerar que, em São Paulo, os esportes começaram a se conformar no período investigado, articulados com a expectativa de que o país parecesse "mais alinhado ou pelo menos um pouco mais próximo do cenário de modernização dos países europeus", ${ }^{29}$ num momento em que se consagrou a "hegemonia europeia sobre todo o globo terrestre, que viu seus modos de vida, usos, costumes, formas de pensar, ver e agir" serem "transformados em modelos inspiradores de novas guinadas culturais".

Assim sendo, tendo em conta que se tratou de um processo de trânsito cultural que nos permite lançar um olhar sobre nossa formação societária, esperamos também entender como as iniciativas dos clubes de críquete tiveram relação com o desenvolvimento de outros esportes, entre os quais o futebol, práticas que se tornariam muito valorizadas no decorrer do século XX.

\section{As primeiras iniciativas}

A partir dos anos 1850, na cidade de São Paulo, cresceu o número de clubes, especialmente os de caráter político e literário, ${ }^{30}$ mas também aqueles com fins recreativos, destinados, entre outras coisas, a promover bailes, apresentações musicais e dramatúrgicas. À exceção da Concórdia Paulistana,

\footnotetext{
${ }^{27}$ MELO, Victor Andrade de. A sociabilidade britânica no Rio de Janeiro do século XIX: os clubes de cricket. Almanack, n. 16, Guarulhos, ago. 2017a, p. 168-205. ISSN 2236-4633. Disponível em: <http://www.scielo.br/pdf/alm/n16/2236-4633-alm-16-00168.pdf>. Acesso em: 5 abr. 2019. DOI: http://dx.doi.org/10.1590/2236-463320171604.

${ }^{28}$ GRAHAM, Richard. Grã-Bretanha e o início da modernização no Brasil. 1850-1914. São Paulo: Brasiliense, 1973; FREYRE, Gilberto. Ingleses no Brasil. $2^{a}$ edição. Rio de Janeiro: José Olympio/MEC, 1977; BETHELL, Leslie. O Brasil no mundo. In: CARVALHO, José Murilo (coord.). História do Brasil nação (1808-2010), vol. 2: A construção nacional (1830-1889). Rio de Janeiro: Objetiva, 2012, p. 131-178.

${ }^{29}$ SALIBA, Elias Thomé. Cultura. As apostas na República. In: SCHWARCZ, Lília Moritz (coord.). História do Brasil nação (1808-2010), vol. 3: A abertura para o mundo (1889-1930). Rio de Janeiro: Objetiva, 2012, p. 239-294, p. 239.

${ }^{30}$ Ver Memórias da Associação Culto à Ciência, n. 3, 30 de julho de 1859, p. 38.
} 
fundada em 1838, naquela década foram criadas muitas sociedades dançantes, entre as quais o Cassino Paulistano. ${ }^{31}$

Essas experiências associativas anteciparam em alguns anos, como ocorrera na Corte, ${ }^{32}$ a criação de clubes esportivos. Na capital paulistana, mais usuais na última década do século, ${ }^{33}$ a primeira agremiação dessa natureza foi fundada por britânicos em 1872: o São Paulo Cricket Club. Desde o início, deixou-se claro seu intuito e inspiração - introduzir "um jogo que é geralmente adotado na Europa". ${ }^{34}$ A partida inaugural foi disputada, em junho, contra uma equipe denominada Wanderers, também integrada por gente da colônia..$^{35}$

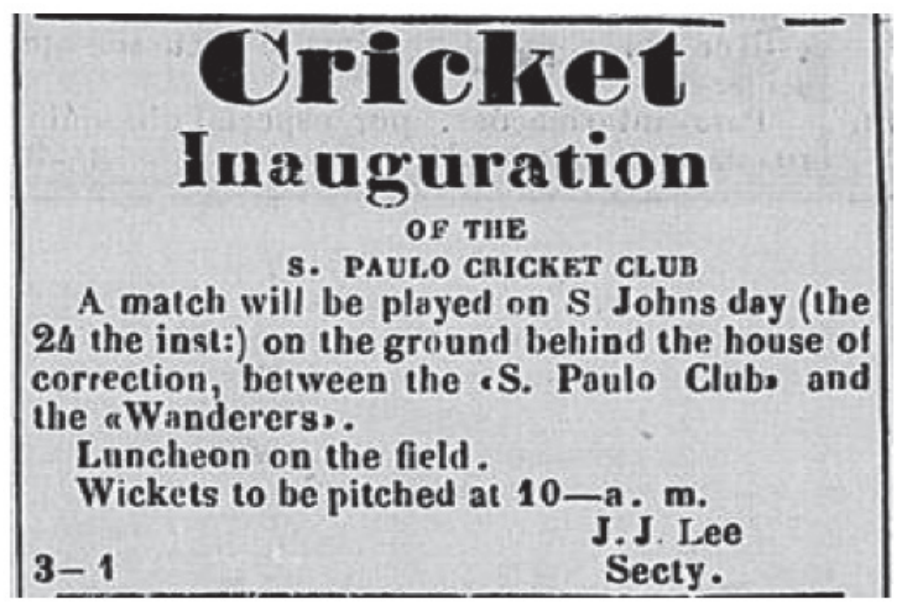

Imagem 1 - Correio Paulistano, 19 de junho de 1872, p. 3.

A notícia anuncia a partida inaugural de críquete disputada entre as equipes São Paulo Cricket Club e a equipe Wanderers, indício de que a prática começava a melhor se estruturar na cidade.

\footnotetext{
${ }^{31}$ MELO, Victor Andrade de $\mathcal{E}$ SANTOS, Flávia da Cruz. Escola de virtudes..., op. cit., 2018.

${ }^{32}$ MELO, Victor Andrade de. Educação do corpo - bailes no Rio de Janeiro do século XIX: o olhar de Paranhos. Educação e Pesquisa, vol. 40, n. 3, São Paulo, jul. 2014, p. 751-766. ISSN 1678-4634. Disponível em: <http://www.scielo.br/pdf/ep/2014nahead/aop1410.pdf>. Acesso em: 5 abr. 2019. DOI: https://doi.org/10.1590/S1517-97022014005000004.

33 GAMBETA, Wilson. A bola rolou: o velódromo paulista e os espetáculos de futebol. São Paulo: Editora Sesi, 2015.

${ }^{34}$ Correio Paulistano, 27 de maio de 1872, p. 4.

${ }^{35}$ Correio Paulistano, 19 de junho de 1872, p. 3. Como ocorreu no Rio de Janeiro, cf. MELO, Victor Andrade de. A sociabilidade britânica no Rio de Janeiro do século XIX..., op. cit., 2017a, é possível que jogos da modalidade fossem antes disputados de maneira menos formal. Entretanto, não conseguimos indícios dessas ocasiões.
} 
O ground do primeiro clube de críquete de São Paulo localizava-se "atrás da Casa de Correção", 36 isto é, no bairro da Luz, onde um grupo de britânicos foi morar na década de 1860 tendo em vista a construção da ferrovia São Paulo Railway. A inauguração da estação da Luz em 1865 marcou o início do auge econômico da região, que incluía o vizinho Campos Elíseos onde se instalaram as elites cafeicultoras. Consideremos que essa proximidade pode ter estimulado os trânsitos culturais, a tomada de conhecimento de novas manifestações culturais.

Com tal movimentação não surpreende que outras diversões tenham se organizado na área, inclusive corridas de cavalo. ${ }^{37}$ A Luz foi o pioneiro espaço desses páreos até a criação, em 1875, do Clube de Corridas Paulistano, futuro Jockey Clube de São Paulo, que instalou seu hipódromo na Mooca.

Na Luz, as duas modalidades - críquete e turfe - ocupavam o mesmo espaço. Tratava-se da Chácara do Campo Redondo, também conhecida como Campo Mauá, terreno antes pertencente ao barão de Mauá, que o passou à propriedade da São Paulo Railway. Loteado pela empresa, serviu de terreno para residências e novos logradouros públicos. ${ }^{38}$

A criação tardia de uma agremiação de críquete, se comparada com a Corte - onde desde os anos 1830 há evidências de jogos e o primeiro clube surgiu em $1854^{39}$-, tem relação com o fato de que somente a partir da década de 1860 aumentou o número de britânicos na capital paulistana. A propósito, depois das notícias de fundação do São Paulo Cricket Club, não conseguimos mais identificar muitos anúncios de eventos da modalidade. Teria a sociedade encontrado dificuldades de funcionamento? Não necessariamente. No caso do Rio de Janeiro, por exemplo, as iniciativas dos britânicos nem sempre chegavam aos jornais de maior circulação. Eram anunciadas nos periódicos publicados em inglês, sendo esse um indicador de que a colônia se mantinha relativamente afastada da sociedade local. ${ }^{40}$

Houve, contudo, iniciativas de maior relacionamento. Em maio de 1875, um anúncio assinado por W. L. Broadbent convidou o “público desta capital

\footnotetext{
36 Correio Paulistano, 19 de junho de 1872, p. 3.

37 BRUNO, Ernani Silva. História e tradições da cidade de São Paulo..., op. cit., 1954a.

${ }^{38}$ Para um debate sobre a Chácara ver SILVA, Elisangela Maria. Práticas de produção e apropriação do espaço em São Paulo: a concessão de terras municipais através das cartas de datas (1850-1890). Dissertação de mestrado em Arquitetura e Urbanismo, Universidade de São Paulo, São Paulo, 2012.

39 MELO, Victor Andrade de. A sociabilidade britânica no Rio de Janeiro do século XIX..., op. cit., 2017 a.

40 Idem.
} 
de cuja presença depende o brilhantismo e a animação de que há mister"t1 para assistir uma partida a ser disputada entre o São Paulo Cricket Club e o Anglo Brazilian Cricket Club, agremiação fluminense. Em A Província de São Paulo também foram convocados os paulistanos "para animar uma diversão a todos os respeitos útil".42

Nos anúncios, explicitava-se uma representação usualmente mobilizada ao redor da modalidade, a ideia de que era uma expressão do processo de civilização e progresso para o qual o São Paulo Cricket Club contribuiria ao "desenvolver entre nós o gosto pelo jogo adotado nas principais escolas da Inglaterra e da Alemanha, pelas vantagens higiênicas que dele resultam".43 Aderindo discursivamente ao ideário moderno, elencou-se uma manifestação dos países europeus como exemplo a ser seguido.

Há que se considerar algumas especificidades desse evento. Uma delas é o fato do anúncio, ao contrário dos anteriores veiculados em inglês, ter sido publicado em português, um sinal de que existia algum interesse em ampliar os envolvidos. A propósito, a agremiação fluminense anunciada, o Anglo Brazilian Cricket Club, contava com lusófonos como membros e dirigentes (brasileiros e portugueses), não só britânicos, como era usual na ocasião (MELO, 2017a).44

Mesmo com tal intenção, ainda que tenha sido observado "o concurso de grande número de nacionais", ${ }^{45}$ destacou-se mesmo a presença de "muitas das famílias inglesas aqui estabelecidas". Percebe-se uma ambiguidade usual entre os britânicos instalados no Brasil. De um lado, desejavam manter seus círculos restritos. De outro, investiam em certos relacionamentos mais amplos e amistosos a fim de reduzir o estranhamento e os estigmas que os cercavam, bem como fortalecer alianças de negócios.

Na verdade, constatamos que quem esteve em São Paulo não foi o Anglo-Brazilian Cricket Club, mas, sim, o Rio Cricket Club, ${ }^{46}$ agremiação tipicamente britânica que, criada em 1872 - a partir da experiência do British Cricket Club (fundado na década de 1850) -, tornou-se uma das mais importantes e longevas sociedades de críquete da capital nacional. ${ }^{47}$ Não sabemos se a mudança se deveu a uma decisão dos envolvidos ou se se tratou de um

\footnotetext{
${ }^{41}$ Correio Paulistano, 27 de maio de 1875, p. 4.

42 A Província de São Paulo, 26 de maio de 1875, p. 2.

43 Idem, p. 2.

${ }^{44}$ MELO, Victor Andrade de. A sociabilidade britânica no Rio de Janeiro do século XIX..., op. cit., 2017 a.

45 A Província de São Paulo, 26 de maio de 1875, p. 2.

${ }^{46} \mathrm{O}$ Globo, 5 de junho de 1875, p. 3.

${ }^{47}$ MELO, Victor Andrade de. A sociabilidade britânica no Rio de Janeiro do século XIX..., op. cit., 2017 a.
} 
equívoco do periódico. De toda forma, vale considerar que o cronista de $O$ Globo $^{48}$ sugeriu ter sido uma disputa entre "ingleses residentes nessa cidade e ingleses que vieram da Corte". ${ }^{9}$

Uma observação relevante foi a liderança e participação nas equipes de Peter Miller (São Paulo) e George Cox (Rio de Janeiro). O primeiro era tio de Charles Miller, o segundo era pai de Oscar Cox, ambos apontados como pioneiros nos mitos fundadores do futebol nas duas cidades. Típicos esportistas à moda britânica, também praticantes do rúgbi, atletismo e beisebol, ${ }^{50}$ suas trajetórias ajudam a entender o forjar de nosso campo esportivo. Circulando entre brasileiros e anglófonos, são um exemplo das múltiplas pontes que houve a estabelecer os trânsitos culturais.

O encontro foi marcado por muitas celebrações. No jantar de encerramento, realizado no Hotel de França, um dos mais importantes da cidade à ocasião, se fez questão de saudar "Sua Majestade o Imperador e Sua Majestade a Rainha da Inglaterra". ${ }^{51}$ Deve-se destacar que as agremiações de estrangeiros comumente entabulavam iniciativas marcadas pela declaração de uma dupla lealdade - ao país em que viviam e à nação de origem (ao menos de seus ascendentes)(MELO, 2014). ${ }^{52}$

Esse tipo de procedimento foi comum em outras ocasiões. Em evento realizado entre "ingleses fluminenses" e "ingleses paulistas" ${ }^{\text {"53 }}$ em julho de 1878, na sede do Rio Cricket Club, o brinde foi levantado também ao presidente dos Estados Unidos, para além dos monarcas de Brasil e Reino Unido. ${ }^{54}$

\footnotetext{
${ }^{48}$ Até o momento, não conseguimos mais informações sobre esse periódico.

49 O Globo, 4 de junho de 1875, p. 3.

${ }^{50}$ MELO, Victor Andrade de $\mathcal{E}$ GONÇALVES, Michelle Carreirão. Antes do american way of life: experiências com o baseball no Rio de Janeiro e São Paulo da transição dos séculos XIX e XX. Revista de História da Unisinos, vol. 22, n. 3, São Leopoldo, 2018, p. 442-452. ISSN 2236-1782. Disponível em: <http://revistas.unisinos.br/index.php/historia/article/view/htu.2018.223.09>. Acesso em: 5 abr. 2019. DOI: 10.4013/htu.2018.223.09.

${ }^{51} O$ Globo, 5 de junho de 1875, p. 3.

52 MELO, Victor Andrade \& PERES, Fábio de Faria. A gymnastica no tempo do Império. Rio de Janeiro: 7 Letras, 2014.

53 As denominações "ingleses do Rio de Janeiro", "ingleses de São Paulo", "anglo-fluminense" e "anglo-paulista" foram utilizadas em diversas ocasiões. Ver, por exemplo, Correio Paulistano, 11 de setembro de 1883, p. 1.

${ }^{54}$ Anglo Brazilian Times, 23 de julho de 1878, p. 4. Nessa ocasião, o periódico celebrou que os oficiais diplomáticos voltaram a frequentar as atividades sociais da colônia.
} 
Victor Andrade Melo e Eduardo Souza Gomes Os britânicos e os clubes de cricketna São Paulo do século XIX (anos 1870-1890)

Isso tem a ver com o fato de que norte-americanos usualmente frequentavam os mesmos espaços sociais que os britânicos. ${ }^{55}$

Nesse evento, o público majoritariamente foi constituído por anglófonos e seus familiares, ainda que alguns brasileiros também se fizessem presentes. De fato, esses encontros eram considerados como oportunidades de unir a colônia e celebrar sua cultura em comum. Em certa ocasião, ressaltou um cronista:

...se um jogador de críquete se comprometer a jogar em uma certa hora, ele dever estar lá na hora inglesa para lutar sua batalha amigável tão pontualmente quanto ele faria se ele tivesse que participar de outro tipo de luta não amigável. Tempo inglês é conhecido em todo o mundo e ingleses no Brasil não devem desacreditar sua reputação. ${ }^{56}$

Ao comentar um desses eventos interestaduais, promovido em setembro de 1881 na sede do Rio Cricket, registrando a grande presença de gente da colônia britânica - inclusive de jovens mulheres, algo sempre celebrado ${ }^{57}$-, um cronista do Anglo Brazilian Times enfatizou que se tratava mesmo de uma ocasião para reforçar "os melhores sentimentos em comunidades de anglofalantes". ${ }^{58}$ Como observou Melo, sobre outro encontro, realizado em 1886:

Vejamos como um cronista narrou uma situação de uma partida disputada entre equipes do Rio e São Paulo: "uma dúzia de homens esfuziantes e jogando ao ar seus bonés, dando o reconhecido hip-hip-hip-hurranhing dos anglo-saxões, quando estão se confraternizando para beber uma cerveja, junto com outros homens, para brindar sua adorável amizade".59 O críquete era apresentado como expressão de um estilo de vida de um povo que prezava pelo cavalheirismo e respeito às liberdades individuais.

\footnotetext{
55 Para mais informações ver JEHA, Silvana Cassab. Anphitheatrical Rio! Marítimos americanos na baía do Rio de Janeiro - século XIX. Almanack, n. 6, Guarulhos, 2013, p. 110-132. ISSN 22364633. Disponível em:<http://www.scielo.br/pdf/alm/n6/2236-4633-alm-06-00110.pdf >. Acesso em: 5 abr. 2019. DOI: http://dx.doi.org/10.1590/2236-463320130608; MELO, Victor Andrade de छ GONÇALVES, Michelle Carreirão. Antes do american way of life..., op. cit., 2018.

${ }^{56}$ The Rio News, 13 de junho de 1899, p. 4.

${ }^{57}$ Sobre a valorização da presença feminina nos eventos dos clubes britânicos, ver MELO, Victor Andrade de. A sociabilidade britânica no Rio de Janeiro do século XIX..., op. cit., 2017a. Sobre a maior participação de mulheres nas iniciativas esportivas no Rio de Janeiro da transição dos séculos ver MELO, Victor Andrade de. Mulheres em movimento: a presença feminina nos primórdios do esporte na cidade do Rio de Janeiro (até 1910). Revista Brasileira de História, vol. 27, n. 54, São Paulo, dez. 2007, p. 127-152. ISSN 1806-9347. Disponível em: <http://www.scielo. br/pdf/rbh/v27n54/a08v2754.pdf>. Acesso em: 5 abr. 2019. DOI: http://dx.doi.org/10.1590/ S0102-01882007000200008.

${ }^{58}$ Anglo Brazilian Times, 15 de setembro de 1881, p. 2.

${ }^{59}$ The Rio News, Rio de Janeiro, 24 de setembro de 1886, p. 3.
} 
Para os que estavam distantes da Grã-Bretanha, alguns sequer a conheciam, era uma forma de fortalecer sentimentos de pertença. ${ }^{60}$

A maior regularidade dos eventos interestaduais tornou-se possível graças à implantação da ferrovia entre Rio de Janeiro e São Paulo. Vale lembrar que havia britânicos trabalhando no gerenciamento das empresas férreas, o que facilitou a concessão de benefícios para os cricketers envolvidos (para deslocamento entre as cidades e para passeios nas redondezas). ${ }^{61}$

Há que se ter em conta que se tratava de um momento de introdução do críquete na capital paulistana. Um cronista do The Rio News, em certa ocasião, chegou a sugerir que isso interferiu no resultado, tendo a agremiação carioca vencido com facilidade o desafio. ${ }^{62} \mathrm{Na}$ verdade, jogos entre equipes de Rio de Janeiro e São Paulo tornaram-se uma saída para manter ativa a prática da modalidade, minimizando a falta de estímulo que havia em função do reduzido número de "atletas" (embora usualmente tenha sido grande o público a assistir os confrontos). ${ }^{63}$

Chegou-se a pensar em estabelecer um calendário de disputas entre os clubes das duas cidades, bem como em formar times mistos para participar de partidas a serem promovidas na Argentina. ${ }^{64}$ De toda forma, eram iniciativas que contavam majoritariamente com membros da colônia, ligadas a seus interesses, embora não devamos desconsiderar os impactos que podem ter tido em grupos de nacionais em função da movimentação decorrente.

Vale ter em conta que, na capital paulistana, era mais restrita outra possibilidade de confraternização usual nas agremiações de anglófonos: a promoção de partidas com tripulantes de embarcações britânicas, como constantemente havia na Corte/Distrito Federal, como as que ancoravam na baía de Guanabara. ${ }^{65}$ Isso somente ocorria em São Paulo quando esses tripulantes subiam a serra vindos do porto de Santos como foi o caso do certame realizado, em julho de 1879, entre o São Paulo Cricket Club e a equipe do navio H. N. S. S. Mallard and Elk. ${ }^{66}$ Tratava-se de mais uma ocasião em que

\footnotetext{
${ }^{60}$ MELO, Victor Andrade de. A sociabilidade britânica no Rio de Janeiro do século XIX..., op. cit., 2017a., p. 190.

${ }^{61}$ Ver, por exemplo, $O$ Globo, 5 de junho de 1875, p. 3.

${ }^{62}$ The Rio News, 7 de setembro de 1881, p. 1.

${ }^{63}$ MELO, Victor Andrade de. A sociabilidade britânica no Rio de Janeiro do século XIX..., op. cit., 2017a.

${ }^{64}$ Anglo Brazilian Times, 15 de setembro de 1881, p. 2.

${ }^{65}$ MELO, Victor Andrade de. A sociabilidade britânica no Rio de Janeiro do século XIX..., op. cit., 2017a.

${ }^{66}$ The Rio News, 5 de agosto de 1879, p. 3.
} 
se celebrava a cultura britânica, encarados os marítimos como portadores dos valores e mensagens do Reino Unido.

Alguns hábitos britânicos começaram a ser mais valorizados quando, no decorrer do último quartel do século XIX, se diversificou a estrutura de entretenimentos da cidade (MELO, 2017a). ${ }^{67}$ Nos anos 1880, alguns setores passaram, inclusive, a sugerir que se deveria dar maior atenção aos esportes, assim como já se observava na Corte e especialmente em países europeus encarados como exemplos de civilização a serem seguidos, nos quais era usual o discurso acerca do valor dos exercícios físicos para a saúde e higiene. ${ }^{68}$

Sugeriu-se que os "britânicos paulistanos" deveriam dar maior atenção aos "exercícios athleticos" (corridas, arremessos e saltos), primórdios do atletismo que no Rio de Janeiro já era mais praticado, destacando-se as festividades anuais conhecidas como British Amateur Athletic Sport (MELO, 2017a). ${ }^{69}$ Para um cronista,

...aqueles que souberem compreender as funestas consequências que resultam para a mocidade brasileira, e, sobretudo, para a mocidade das escolas, do espiritualismo da sua educação, não poderão deixar de aplaudir os esforços de alguns amadores fluminenses que têm tentado introduzir, nos nossos costumes, o gosto pelos esportes atléticos. ${ }^{70}$

Um periodista do Correio Paulistano, com algum exagero, mas não de todo equivocado, sugeriu que "Há anos que existe em São Paulo, não um clube de críquete devidamente organizado, mas antes um grupo de cavalheiros, na maior parte pertencentes à colônia inglesa, os quais (...) têm dado boas provas da sua perícia". ${ }^{71}$ A matéria, inclusive, apresentou as regras básicas do esporte a fim de ampliar a atenção do público e atrair maior número de interessados.

Essa posição é um indício de que a modalidade era ainda pouco conhecida do grande público, muito restrita aos britânicos e mesmo entre esses nem tão ativa assim. De fato, em São Paulo, foi somente no decorrer dos anos 1880 que as atividades de críquete ganharam maior dinamismo, inclusive em função da criação de novas agremiações.

\footnotetext{
${ }^{67}$ MELO, Victor Andrade de $\mathcal{E}$ SANTOS, Flavia da Cruz. Deslizando rumo ao progresso: a patinação em São Paulo..., op. cit., 2017a.

${ }^{68}$ Ver Correio Paulistano, 18 de agosto de 1882, p. 3.

${ }^{69}$ MELO, Victor Andrade de. A sociabilidade britânica no Rio de Janeiro do século XIX..., op. cit., 2017 a.

${ }^{70}$ Correio Paulistano, 18 de agosto de 1882, p. 2.

${ }^{71}$ Correio Paulistano, 8 de setembro de 1882, p. 2.
} 


\section{Consolidando o críquete, abrindo novos caminhos esportivos}

Nas duas últimas décadas do século XIX, cresceu o número de britânicos não só na capital paulista como também em outras cidades próximas. Em Campinas e Santos, isso se deu em função da expansão do comércio e da indústria. Nesse cenário, surgiram novas agremiações que dinamizaram a cena do críquete na província.

Uma longa crônica sobre um jogo realizado em 1882, entre o São Paulo Cricket e o Campinas Cricket Club, disputado num ground em Jundiaí, dá conta de que a colônia passou a se envolver mais intensamente com a modalidade, bem como a perspectivar maior presença de brasileiros em suas atividades. ${ }^{72}$

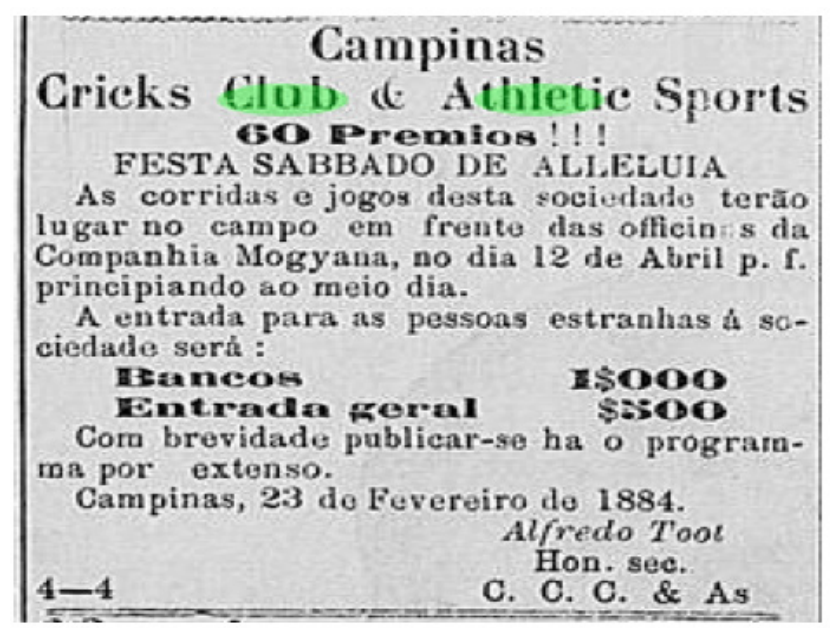

Imagem 2 - Correio Paulistano, 9 de março de 1884, p. 4.

O anúncio informa os valores cobrados para pessoas "estranhas à sociedade" assistirem ao jogo de críquete, um indício de maior abertura dos eventos.

A nova agremiação, que recebeu boa atenção da imprensa, disputava jogos locais ${ }^{73}$ ou contra equipes de outras cidades - de São Paulo ${ }^{74}$ de San-

\footnotetext{
72 The Rio News, 5 de julho de 1882, p. 2; The Rio News, 5 de setembro de 1882, p. 4.

${ }^{73}$ Correio Paulistano, 27 de junho de 1885, p. 2.

${ }^{74}$ The Rio News, 5 de setembro de 1882, p. 4.
} 
tos $^{75}$ e do Rio de Janeiro. ${ }^{76}$ Promovia também festivais esportivos abertos ao público não associado, bastante celebrados e frequentados por gente que não pertencia à colônia britânica. É de importância destacar que as relações entre a capital paulistana e o interior aumentaram em função da instalação das ferrovias e do incremento de negócios. Nesse cenário, intensificou-se a circulação de ideias e padrões de cultura.

Em Santos, a princípio, o críquete foi jogado de maneira menos formal nas praias. Em 1889, foi criado o Santos Athletic Club, uma iniciativa de funcionários da São Paulo Railway e da The City of Santos Improvements Company (empresa britânica responsável por serviços urbanos como distribuição de água, iluminação, transporte público). Existente até os dias atuais, a agremiação ficou conhecida como o "clube dos ingleses". ${ }^{77}$

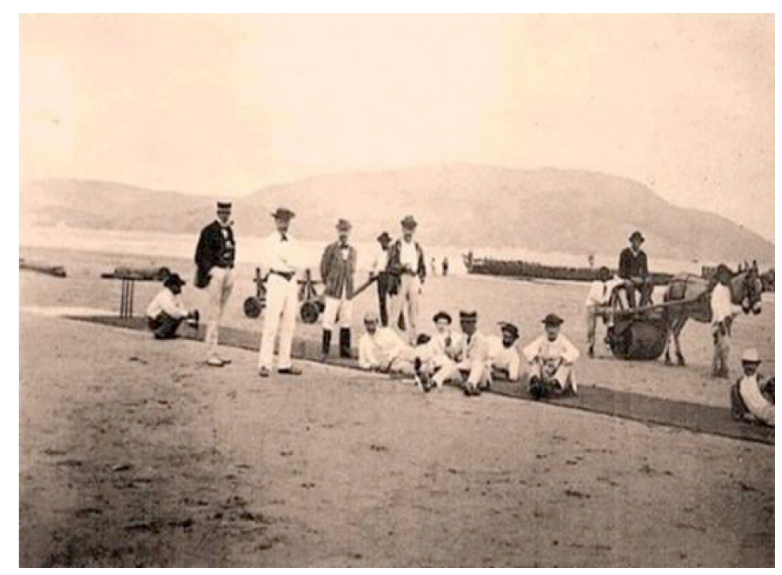

Imagem 3 - Críquete do Santos Athletic Club

Naquela cidade, a praia foi utilizada como espaço para a prática do críquete.

Disponível em: http://www.novomilenio.inf.br/santos/h0171c.htm.

\footnotetext{
75 The Rio News, 5 de dezembro de 1885, p. 3.

76 The Rio News, 15 de setembro de 1888, p. 2.

77 VIEIRA, Marina Tucunduva Bittencourt Porto. Esporte, cidade e modernidade: Santos. In: MELO, Victor Andrade de (org.). Os sports e as cidades brasileiras: transição dos séculos XIX e XX. Rio de Janeiro: Apicuri, 2010, p. 71-95, p. 77.
} 
Victor Andrade Melo e Eduardo Souza Gomes Os britânicos e os clubes de cricketna São Paulo do século XIX (anos 1870-1890)

Em 1899, foi inaugurada sua sede no bairro de José Menino. Tratouse de um grande investimento (estimado em torno de 45 contos de réis), ${ }^{78}$ justificado pela diretoria por tornar mais confortáveis as atividades sociais e esportivas da agremiação. Efetivamente, a despeito das dificuldades financeiras, o espaço tornou-se importante especialmente para os praticantes de críquete e tênis que puderam aperfeiçoar seus estilos de jogo. A conquista foi saudada como expressão do espírito empreendedor dos britânicos, bem como da disposição de estabelecer maior relação com os personagens mais importantes da cidade. ${ }^{79}$ Uma vez mais, percebemos a já citada ambiguidade dos britânicos, algo que, de toda forma, também ajudou a gestar espaços de interface que se constituíram em potenciais fóruns de trânsito cultural.

A essa altura, novas equipes de britânicos já tinham sido criadas. ${ }^{80}$ Nos anos de 1891 a 1893, muitos jogos foram realizados, ${ }^{81}$ dando a impressão de que houve mesmo um calendário que se assemelhava à experiência melhor estruturada do Rio de Janeiro. ${ }^{82}$ Além disso, foram promovidos muitos festivais esportivos à moda britânica, cuja programação era composta por corridas a pé e de bicicletas, arremessos, saltos, jogos de tênis. ${ }^{83}$ Tais eventos eram em geral abertos ao público, ${ }^{84}$ estabelecendo-se como oportunidades de maior contato entre os anglófonos e os membros da elite local, presença constante nas iniciativas do Santos Athletic Club. ${ }^{85}$

Uma epidemia de febre amarela e varíola ${ }^{86}$ interferiu nesse dinamismo esportivo, mas não chegou a abalar o interesse pelo tema. Nos anos finais do século, recrudesceu o número de partidas promovidas, bem como o entu-

\footnotetext{
${ }^{78}$ Para que se tenha uma ideia, em 1899 era vendida por 38 contos de réis uma fazenda com 10 mil pés de café, casas de morada e para colonos, pedaço de mata virgem, bom abastecimento de água, além de 5 alqueires para pasto. Cf. Lavoura e Comércio, 8 de setembro de 1899, p. 4.

${ }^{79}$ Ver The Rio News, 6 de dezembro de 1898, p. 5 e The Rio News, 9 de maio de 1899.

${ }^{80}$ Ver, por exemplo, The Rio News, 8 de dezembro de 1890, p. 3.

${ }^{81}$ Ver, por exemplo, The Rio News, 21 de junho de 1892, p. 3.

${ }^{82}$ MELO, Victor Andrade de. A sociabilidade britânica no Rio de Janeiro do século XIX..., op. cit., 2017a.

${ }^{83}$ Ver The Rio News, 12 de maio de 1891, p. 3.

${ }^{84}$ The Rio News, 19 de maio de 1891, p. 8.

${ }^{85}$ Ver, por exemplo, The Rio News, 19 de julho de 1898, p. 7.

${ }^{86}$ A cidade vinha passando por tais problemas desde a década de 1870. Na última década do século, eles se acentuaram com o crescimento do porto e aumento populacional. Para mais informações ver TELAROLLI JÚNIOR, Rodolfo. Imigração e epidemias no Estado de São Paulo. História, Ciências, Saúde - Manguinhos, vol. 3, n. 2, Rio de Janeiro, 1996, p. 265-283. ISSN 1678-4758. Disponível em: <http://www.scielo.br/pdf/hcsm/v3n2/v3n2a04.pdf>. Acesso em: 5 abr. 2019. DOI: http://dx.doi.org/10.1590/S0104-59701996000200004.
} 
siasmo com a prática. ${ }^{87}$ Anualmente, passou a ser inclusive divulgado um calendário multiesportivo (críquete, tênis, atletismo). ${ }^{88}$ Além disso, se tornaram mais usuais as partidas disputadas com tripulações de embarcações britânicas.

De toda forma, os jogadores em geral seguiam sendo membros da colônia britânica. Havia, por vezes, uma curiosa partida (usualmente também promovida no Rio de Janeiro), Niggers x Whites, a primeira equipe formada por britânicos nascidos na América, a segunda pelos natos no Reino Unido. ${ }^{89}$ Não se tratava de qualquer forma de ruptura ou conflito entre os anglófonos, antes uma maneira de, reconhecendo certas diferenças, celebrar uma cultura em comum.

Na capital paulistana, também houve novidades na cena do críquete com a criação de uma nova agremiação que assumiria papel protagonista, o São Paulo Athletic Club. Há que se ter em conta, na última década do século XIX, o denotado crescimento do setor industrial. Entre 1890 e 1899, foram instaladas na cidade 299 novas indústrias. ${ }^{90}$

Uma vez mais, foram notáveis o crescimento populacional e as mudanças na infraestrutura urbana. ${ }^{91} \mathrm{O}$ processo de transformação da cidade se acentuou quando Antônio da Silva Prado se tornou intendente, cargo no qual permaneceu entre 1899 e 1911. Suas ações procuraram enfatizar o processo de sintonização de São Paulo com o ideário e imaginário da modernidade. Foi o responsável por obras importantes, entre as quais a instalação da luz elétrica e a construção do Teatro Municipal.

Prado foi um dos fundadores do Automóvel Clube e um entusiasta da prática esportiva. Era de propriedade de sua família o Velódromo Paulistano, inaugurado em 1892, local que, nos seus primórdios, acolheu corridas a pé e de velocípedes. Por lá, foram também promovidos jogos de críquete e fu-

\footnotetext{
${ }^{87}$ Ver, por exemplo, The Rio News, 9 de julho de 1895, p. 7.

${ }^{88}$ Ver, por exemplo, The Rio News, 18 de abril de 1899, p. 7.

89 The Rio News, 30 de maio de 1893, p. 5.

${ }^{90}$ ROLNIK, Raquel. São Paulo, início da industrialização: o espaço é político. In: KOWARICK, L. (org.). As lutas sociais e a cidade. São Paulo: Paz e Terra / Unrisd, 1988, p. 207-245.

${ }^{91}$ Em 1836, São Paulo tinha 21.993 habitantes (sendo 5.319 escravos). Em 1854, eram 25.554 pessoas (5.571 escravos e 762 estrangeiros). Em 1872, eram 31.385 (3.828 escravos e 2.459 estrangeiros, 68 ingleses, 29 norte-americanos). Nesse caso, deve-se ter em conta que Cotia foi desmembrada (se considerada, a cidade teria 36.409). Em 1886, eram 47.697 (se considerar o território original de 1836, com Cotia e Guarulhos, seriam 62.223). Eram 12.290 estrangeiros, 255 ingleses. Em 1890, eram 64.394 (mas seriam 86.681 se considerássemos o território original), 14.330 estrangeiros. Cf. BASSANEZI, Maria Silvia C. Beozzo. São Paulo do passado: dados demográficos. Campinas: Núcleo de Estudos da População/Unicamp, 2000.
} 
Victor Andrade Melo e Eduardo Souza Gomes Os britânicos e os clubes de cricketna São Paulo do século XIX (anos 1870-1890)

tebol, tendo sido o principal estádio das partidas do primeiro Campeonato Paulista desta modalidade, organizado em 1902.

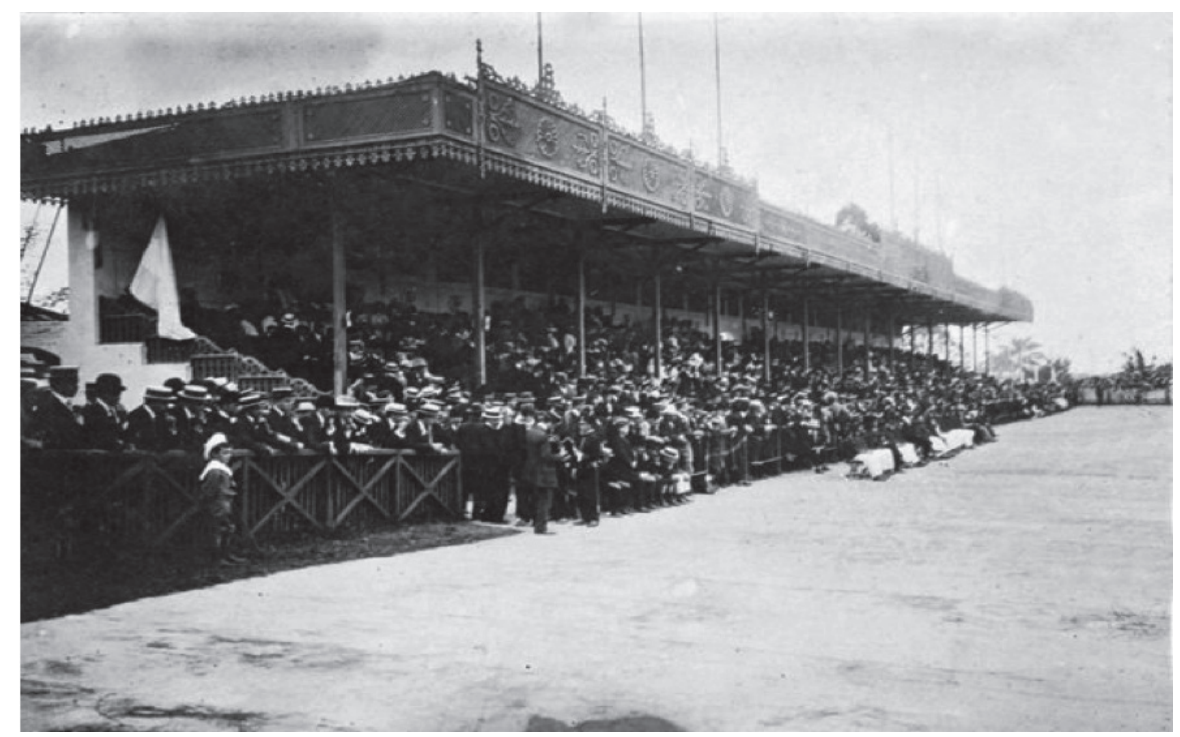

Imagem 4 - Velódromo Paulistano (rua da Consolação esquina de rua Martinho Prado). Espaço que abrigou os primeiros jogos de criquete, rugby e futebol em São Paulo.

Fonte: Centro Pró-Memória do Clube Athletico Paulistano

O velódromo foi também, até 1915, sede do Clube Atlético Paulistano, no qual se destacou na liderança o filho do notório intendente, Antônio Prado Júnior, um dos mais importantes personagens do esporte nacional nas primeiras décadas do século XX (bem como político influente que chegou a ser prefeito do Distrito Federal). ${ }^{92}$

\footnotetext{
${ }_{92}$ Para mais informações ver FERNANDEZ, Renato Lanna. A concepção de esporte em Antônio Prado Júnior: o amadorismo como princípio civilizatório e regenerador. In: XXVIII SIMPÓSIO NACIONAL DE HISTÓRIA. Florianópolis: Anpuh, 2015. Anais. Disponível em: <http://www. snh2015.anpuh.org/resources/anais/39/1433603253_ARQUIVO_TEXTOPARAANPHU2015.pdf>. Acesso em: 5 abr. 2019; GAMBETA, Wilson. A bola rolou... , op. cit., 2015; TOLEDO, Roberto Pompeu de. A capital da vertigem: uma história de São Paulo de 1900 a 1954. Rio de Janeiro: Objetiva, 2015.
} 
Victor Andrade Melo e Eduardo Souza Gomes Os britânicos e os clubes de cricketna São Paulo do século XIX (anos 1870-1890)

O São Paulo Athletic Club participou ativamente desse quadro de mudanças. Fundado em 1888, ${ }^{93}$ com sede na Chácara Dulley, ${ }^{94}$ foi um dos responsáveis pela difusão do esporte na cidade. Mesmo mantendo forte relação com a colônia britânica - os jogos e treinos eram em muitas ocasiões divulgados em inglês ${ }^{95}$ - percebe-se que suas iniciativas eram mais abertas e atraíam maior número de interessados da sociedade paulistana. Em determinado momento, seus anúncios passaram, inclusive, a ser publicados em dois idiomas:

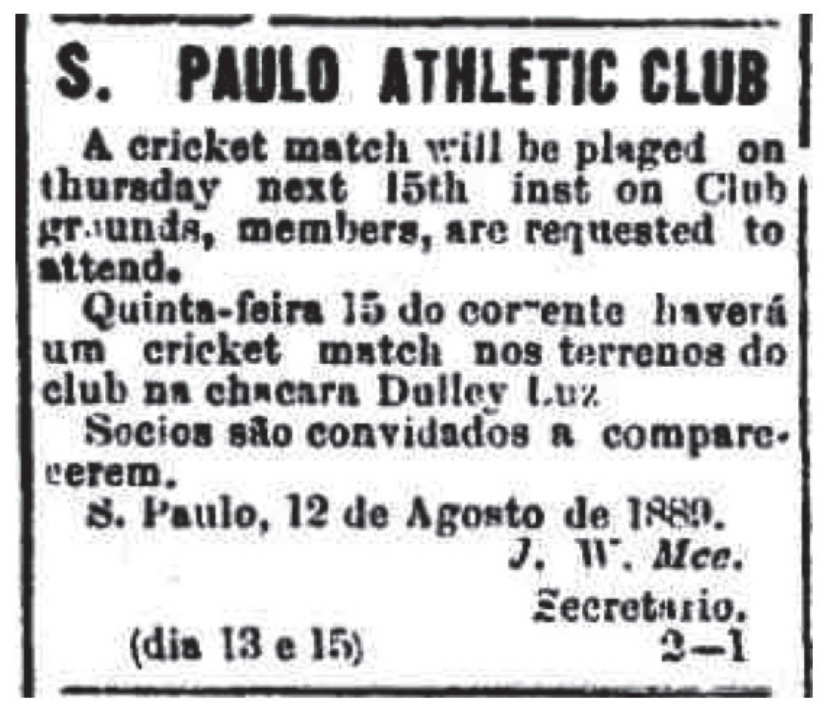

Imagem 5 - A Província de São Paulo, 13 de agosto de 1889, p. 3

Anúncio do São Paulo Athletic Club publicado em português e inglês, indício de que havia algum interesse em atingir um público maior, não somente gente da colônia britânica.

\footnotetext{
${ }^{95}$ Brown e Lanci problematizam a data de fundação do São Paulo Athletic Club, sugerindo, a partir de notícias publicadas no Correio Paulistano, que tenha sido 1876. Cf. BROWN, Matthew $\mathcal{E}$ LANCI, Gloria. Amadores e profissionais: a comunidade britânica na formação do futebol em São Paulo entre 1880 e 1916. In: GOMES, Eduardo de Souza E PINHEIRO, Caio Lucas Morais (org.). Olhares para a profissionalização do futebol: análises plurais. Rio de Janeiro: Multifoco, 2015, p. 92-107. Não conseguimos apurar se tais informações se referem a essa agremiação ou a outra homônima. De toda forma, podemos perceber que a sua atuação começou a ser, de fato, consolidada a partir de 1888.

${ }^{94}$ Originalmente pertencente ao norte-americano Charles Dulley, engenheiro importante da São Paulo Railway, acolheu pioneiros jogos de diversas modalidades. Localizada no bairro do Bom Retiro, também foi utilizada para treinos e partidas de futebol e rúgbi. Para mais informações ver MILLS, John. Charles Miller: o pai do futebol brasileiro. Rio de Janeiro: Panda Books, 2014.

${ }^{95}$ A Província de São Paulo, 31 de agosto de 1888, p. 3; A Província de São Paulo, 24 de março de 1889, p. 3.
} 
Para além da própria dinâmica da cidade - cuja população estava mais atenta às novidades europeias e disposta a se envolver com diferentes entretenimentos -, um dos motivos que contribuiu para o maior reconhecimento público do São Paulo Athletic foi a ampliação das modalidades praticadas. Além do críquete, seus associados organizaram jogos de futebol e rúgbi. ${ }^{96}$ Além disso, o clube promoveu muitos festivais atléticos à moda dos que existiam no Rio de Janeiro e Santos, com a programação composta por corridas, saltos, arremessos. ${ }^{97}$

Esses eventos, em geral, eram abertos a não associados, atraindo, aparentemente, bom número de interessados. ${ }^{98}$ Percebe-se o aumento dos grupos sociais envolvidos, destacando-se a maior presença de mulheres. ${ }^{99}$ Chegaram a ser realizadas partidas "Ladies x Gentlemen", ocasiões que sempre mereceram atenção pela participação da mulher como jogadora e não na assistência, como era usual. ${ }^{100}$

Vale considerar a importância da Chácara Dulley no que tange à ampliação do público esportivo, inclusive no tocante aos encontros entre diferentes estratos sociais. No bairro do Bom Retiro, com o estabelecimento de diferentes fábricas, foi se conformando uma experiência operária que passou a também se cruzar com as iniciativas esportivas, antes mais restritas. No decorrer do tempo, isso iria mesmo interferir na dinâmica dos jogos.

\footnotetext{
${ }^{96}$ Apesar de possuir grande popularidade em diversos países, no Brasil o rúgbi não alcançou esse mesmo status. Ver MELO, Victor Andrade de \& GONÇALVES, Michelle Carreirão. À sombra do futebol: experiências com o rugby nas duas primeiras décadas do século XX. Movimento, Porto Alegre, 2018. No prelo.

${ }^{97}$ Ver, por exemplo, $O$ Estado de S. Paulo, 18 de novembro de 1892, p. 1.

${ }^{98}$ Ver, por exemplo, The Rio News, 29 de outubro de 1895, p. 5; The Rio News, 6 de setembro de 1898, p. 4.

${ }^{99}$ Numa matéria sobre uma partida de críquete disputada entre o Rio Cricket e o Santos Athletic Club, destacou-se esse aspecto. Para mais informações ver The Rio News, 5 de setembro de 1893, p. 5.

${ }^{100}$ The Rio News, 19 de setembro de 1899, p. 3. Ver também The Rio News, 14 de novembro de 1899, p. 5. Outros autores têm chamado a atenção de como o esporte foi um importante âmbito no qual se percebeu pioneiramente o maior protagonismo feminino. Ver, por exemplo, MELO, Victor Andrade de. A sociabilidade britânica no Rio de Janeiro do século XIX..., op. cit., 2017a.
} 


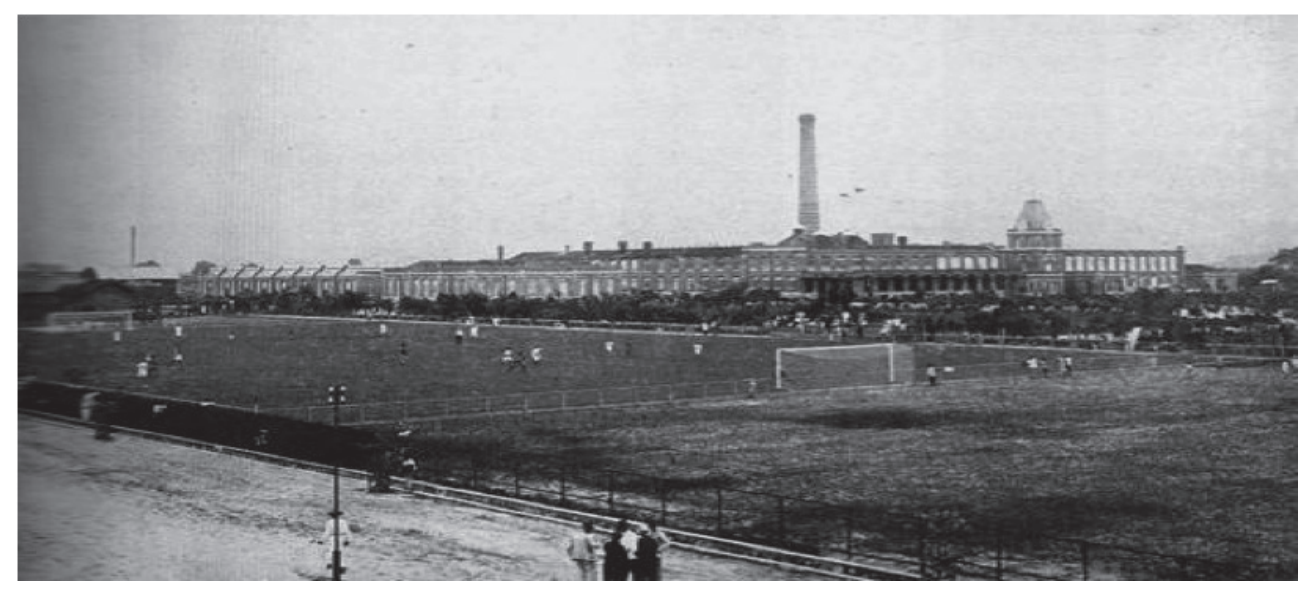

Imagem 6 - A Chácara Dulley, nessa imagem já com campo de futebol, e com uma fábrica ao fundo, foi um dos espaços de maior importância para a difusão dos esportes de São Paulo na transição dos séculos XIX e XX.

Disponível em: http://portaldavarzea.com/conheca-as-historias-dos-primeiros-campos-de-sao-paulo/

Foi naqueles anos finais do século XIX que também começou a se consolidar a fama de Charles Miller, que se destacava pela boa performance em diversas modalidades - críquete, atletismo, beisebol, rúgbi e futebol. Seu desempenho se constituiu em mais um agente motivador para o público. ${ }^{101}$ Um cronista, em certa ocasião, foi categórico: “Nenhum jogador de críquete é mais popular no Brasil. Miller é um verdadeiro sportsman, em todos os seus sentidos". ${ }^{102}$ A cidade que se tornava mais atenta ao "atleticismo", considerado expressão de civilização e estratégia de formação, passou a eleger seus primeiros ídolos esportivos.

Outro aspecto com o qual o São Paulo Athletic Club contribuiu foi o estímulo ao fortalecimento das rivalidades. Isso se tornou notável nas disputas com o Santos Athletic Club. Desde 1890, ${ }^{103}$ diversos foram os jogos promovidos entre ambos, usualmente destacados pela imprensa como ocasiões importantes. ${ }^{104}$ Em 1899, saudou um cronista: "Dois dias do melhor críquete

\footnotetext{
${ }^{101}$ Ver alguns de seus bons resultados em The Rio News, 26 de outubro de 1897, p. 5.

${ }^{102}$ The Rio News, 23 de maio de 1899, p. 4.

${ }^{105} \mathrm{O}$ Mercantil, 26 de julho de 1890, p. 1.

${ }^{104}$ Ver, por exemplo, The Rio News, 17 de outubro de 1893.
} 
Victor Andrade Melo e Eduardo Souza Gomes Os britânicos e os clubes de cricketna São Paulo do século XIX (anos 1870-1890)

jamais visto em Santos". ${ }^{105} \mathrm{O}$ esporte, progressivamente, tornava-se assunto valorizado pela população, processo para o qual a imprensa desempenhou importante papel.

Tornaram-se mais frequentes e celebrados os encontros com equipes do Rio de Janeiro. O Rio Cricket and Athletic Association ${ }^{106}$ foi uma das agremiações que, na década final no século XIX, mais recebeu e se deslocou para realizar confrontos com clubes da capital paulistana e de Santos. ${ }^{107}$ No caso da cidade portuária, havia grande rivalidade pelo cenário do críquete ser muito movimentado. ${ }^{108}$ Bem ao espírito da modalidade e dos britânicos, essas disputas jamais descambaram para a ruptura, sendo sempre celebradas com grande expectativa e entusiasmo pelos envolvidos e associados em geral. ${ }^{109}$

Em 1898, a disputa realizada em Niterói ganhou ares de jogo de seleção, pois as equipes de paulistas e fluminenses foram formadas por um misto das agremiações de cada província. ${ }^{110}$ Um cronista saudou a ocasião dizendo que nunca o críquete despertara tanto entusiasmo no Brasil. ${ }^{111}$

A despeito de certo exagero - nunca foi grande o número de brasileiros que se envolveram como jogadores - inegavelmente o críquete chegava a um grau de movimentação ainda não visto em Santos, Campinas e São Paulo, mas também no Rio de Janeiro, ${ }^{112}$ Recife ${ }^{113}$ e Salvador. ${ }^{114}$ Na capital paulistana, foram utilizados diversos espaços para a realização dos jogos.

\footnotetext{
${ }^{105}$ The Rio News, 23 de maio de 1899, p. 4.

${ }^{106}$ No final do século XIX, o Rio Cricket deixou de existir. Alguns de seus sócios criaram, em Niterói, o Rio Cricket and Athletic Association. Enquanto isso, na antiga sede do Rio de Janeiro, outros associados criaram o Paissandu Cricket Club. Cf. MELO, Victor Andrade de. A sociabilidade britânica no Rio de Janeiro do século XIX..., op. cit., 2017a.

${ }^{107}$ The Rio News, 5 de setembro de 1886.

${ }^{108}$ Ver, por exemplo, The Rio News, 14 de setembro de 1893, p. 5.

${ }^{109}$ The Rio News, 15 de junho de 1888, p. 4.

${ }^{110}$ The Rio News, 13 de setembro de 1898, p. 5.

${ }^{111}$ No ano seguinte, a "seleção" do Rio de Janeiro retribuiu a viagem com uma série de jogos disputados em Santos. Cf. The Rio News, 4 de julho de 1899, p. 3.

${ }^{112}$ Para mais informações ver MELO, Victor Andrade de. A sociabilidade britânica no Rio de Janeiro do século XIX..., op. cit., 2017a.

${ }^{113}$ Para mais informações ver MELO, Victor Andrade de. Para inglês ver? Os clubes de cricket e a sociabilidade britânica em Recife (1865-1906). Territórios e Fronteiras, vol. 10, n. 1, Dourados, jan.-jul. 2017b, p. 161-178. ISSN 2175-0742. Disponível em: <http://ppghis.com/territoriosEfronteiras/index.php/v03n02/article/view/568>. Acesso em: 5 abr. 2019. DOI: http://dx.doi. org/10.22228/rt-f.v10i1.568.

${ }^{114}$ Para mais informações, ver os posts de Coriolano Pereira da Rocha Júnior: $<$ https://historiadoesporte.wordpress.com/2017/02/20/mais-sobre-cricket-em-salvador/ > e <https://historiadoesporte.wordpress.com/2012/07/23/o-criquete-em-terras-baianas/>. Acesso em: 30 ago. 2017.
} 
Além dos já citados Chácara Dulley e Velódromo Paulista, também o Parque Antártica ${ }^{115}$ e a Chácara da Floresta, ${ }^{116}$ entre outros.

Os contatos entre britânicos por meio do críquete chegaram a se estabelecer com outros países. Em uma dessas ocasiões, uma equipe da Argentina veio à capital paulistana jogar contra o São Paulo Cricket Club depois de, na capital federal, enfrentar o Rio Cricket. ${ }^{117}$ Houve também retribuições da visita, times paulistas e fluminenses que viajaram a Buenos Aires para disputar partidas e celebrar os traços culturais britânicos (como de costume, sem esquecer de fazer as saudações aos países envolvidos). ${ }^{118}$

Por todo o mundo, onde estivessem, os britânicos se reuniam ao redor do críquete. Assim também o foi na São Paulo das últimas décadas do século XIX.

\section{À guisa de conclusão}

Mesmo tendo se estruturado melhor no decorrer do século XIX, é possível notar que o críquete sempre se manteve restrito aos clubes e iniciativas de britânicos, não se observando maior participação dos paulistanos como jogadores (ainda que sim como público). A modalidade parece ter sido mesmo mais importante no que tange ao forjar de uma sociabilidade e de uma identidade desse grupo social.

Quando surgia uma agremiação nova, como o São Paulo Railway Cricket Club, ficava claro que se tratava de uma iniciativa da colônia. ${ }^{119}$ Não surpreende que um celebrado colégio ligado aos britânicos, The Anglo-Bra-

\footnotetext{
${ }^{115}$ Construído no final do século XIX pela Companhia Antarctica Paulista, empresa produtora de cervejas, o Parque Antártica se tornou, nos anos iniciais do século XX, um importante estádio de futebol da cidade, tendo acolhido muitos eventos esportivos de diferentes modalidades. Nos anos 1920, foi comprado pelo Palestra Itália (atual S. E. Palmeiras). Para mais informações ver GAMBETA, Wilson. A bola rolou..., op. cit., 2015 e TOLEDO, Roberto Pompeu de. A capital da vertigem..., op. cit., 2015.

${ }^{116} \mathrm{~A}$ Chácara da Floresta acolheu, de início, na primeira década do século XX, atividades de remo dinamizadas pelo Clube Esperia e pelo Clube de Regatas São Paulo. Logo passou também a sediar partidas de futebol, rúgbi e críquete, tendo sido um dos principais espaços esportivos de São Paulo, bem como sede de agremiações como o A. A. Palmeiras e o São Paulo F. C. Para mais informações ver GAMBETA, Wilson. A bola rolou..., op. cit., 2015 e TOLEDO, Roberto Pompeu de. A capital da vertigem..., op. cit., 2015.

${ }^{117} \mathrm{O}$ Estado de São Paulo, 5 de julho de 1890, p. 1.

${ }^{118}$ Ver, por exemplo, O Comércio de São Paulo, 28 de novembro de 1902, p. 1. Houve iniciativas semelhantes com equipes de rúgbi. Cf. MELO, Victor Andrade de \& GONÇALVES, Michelle Carreirão. À sombra do futebol..., op. cit., 2018.

${ }^{119}$ The Rio News, 28 de junho de 1898, p. 5.
} 
zilian School, organizado segundo os moldes do Reino Unido, fizesse questão de oferecer a modalidade a seus alunos. ${ }^{120}$

Não há uma chave explicativa única para determinar o porquê de o críquete, um dos esportes mais difundidos no mundo, não ter sido praticado com maior frequência em São Paulo, tal como em boa parte do Brasil, enquanto outras modalidades se consolidaram.

De toda forma, é possível identificar sua notória importância na difusão de outros esportes. Mesmo que não tenha se popularizado a ponto de se tornar uma das principais alternativas de lazer dos paulistanos, o críquete deixou relevantes marcas na cidade. Suas atividades tornaram-se conhecidas e percebem-se referências à modalidade em diferentes âmbitos.

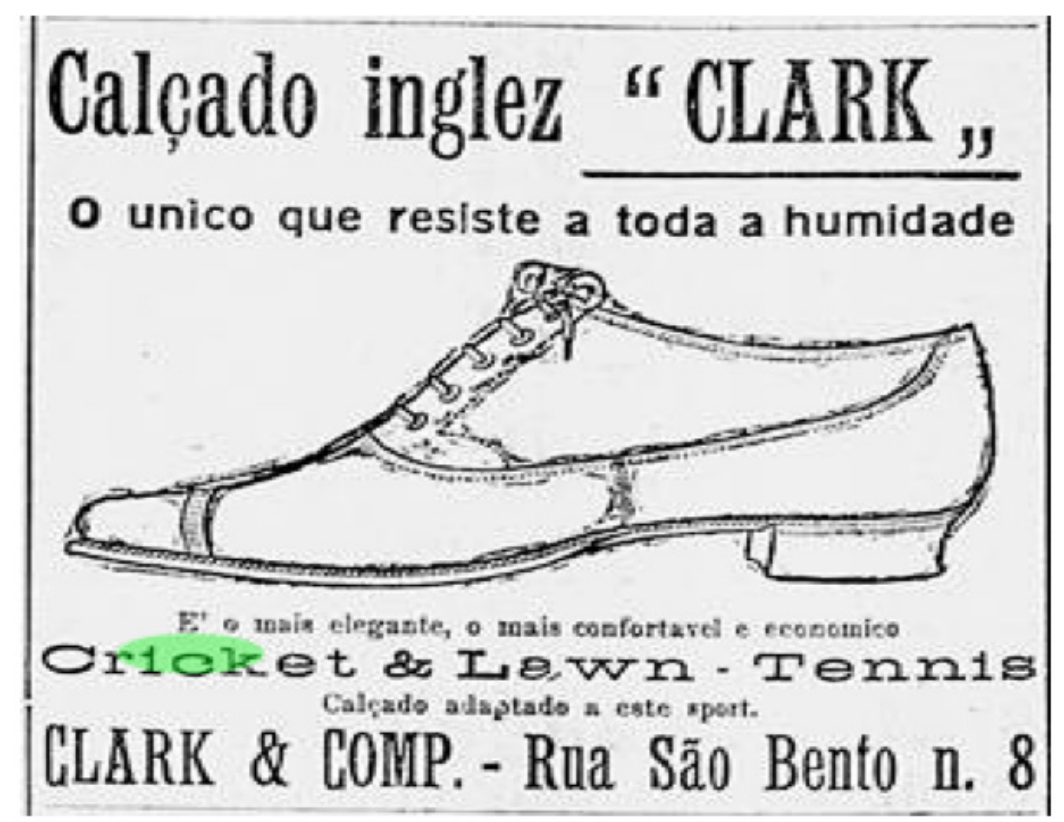

Imagem 7 - Correio Paulistano, 12/4/1902, p. 4

Anúncio de calçado, um indício de como circulavam, de alguma forma, referências ao críquete.

${ }^{120}$ Brazilian Review, 30 de dezembro de 1902, p. 631. 
As iniciativas dos clubes de críquete ajudaram a entabular um processo de trânsito cultural que deu origem a releituras específicas, algo que contribuiu para fortalecer um gosto que já vinha se delineando na cidade. ${ }^{121} \mathrm{Um}$ cronista, ao identificar a influência dos britânicos no desenvolvimento dos esportes, chegou a sugerir que fossem traduzidos para o português os termos em inglês comumente utilizados. ${ }^{122}$

No início do século XX, envolver-se com esportes, para além do espetáculo público já mais amplamente apreciado definitivamente passou a ser entendido como um "ideal do homem moderno". ${ }^{123} \mathrm{O}$ críquete foi um dos "embriões" do desenvolvimento desse olhar para a prática, abrindo caminho, inclusive, para aquela modalidade que se tornaria de fato popular na assistência e prática, o futebol, assunto já investigado por outros autores. ${ }^{124}$

\section{Referências bibliográficas}

AMARAL, Antônio Barreto do. História dos velhos teatros de São Paulo: da Casa da Ópera à inauguração do Teatro Municipal. São Paulo: Governo do Estado de São Paulo, 1979.

ARAÚJO NETO, Miguel Alexandre de. Great Britain, the Paraguayan War and free immigration in Brazil, 1862-1875. Irish Migration Studies in Latin America, vol. 4, n. 3, Bakersfield, jul. 2006. ISSN 1661-6065. Disponível em: <http://www. irlandeses.org/0607_115to132.pdf>. Acesso em: 5 abr. 2019.

BASSANEZI, Maria Silvia C. Beozzo. São Paulo do passado: dados demográficos. Campinas: Núcleo de Estudos da População/Unicamp, 2000.

BETHELL, Leslie. O Brasil no mundo. In: CARVALHO, José Murilo (coord.). História do Brasil nação (1808-2010), vol. 2: A construção nacional (1830-1889). Rio de Janeiro: Objetiva, 2012, p. 131-178.

BOEHRER, George C. A. Da monarquia à república: história do Partido Republicano do Brasil - 1870-1889. Rio de Janeiro: Ministério da Educação e Cultura, Serviço de Documentação, 1954.

BROWN, Matthew $\mathcal{E}$ LANCI, Glória. Amadores e profissionais: a comunidade britânica na formação do futebol em São Paulo entre 1880 e 1916. In: GOMES, Eduardo de Souza $\mathcal{E}$ PINHEIRO, Caio Lucas Morais (org.). Olhares para a profissionalização do futebol: análises plurais. Rio de Janeiro: Multifoco, 2015, p. 92-107.

\footnotetext{
${ }^{121}$ BROWN, Matthew E LANCI, Gloria. Amadores e profissionais..., op. cit., 2015; MELO, Victor Andrade de. A sociabilidade britânica no Rio de Janeiro do século XIX..., op. cit., 2017a.

${ }^{122}$ The Brazilian Review, 20 de outubro de 1903, p. 560.

${ }^{123} \mathrm{O}$ Estado de S. Paulo, 9 de julho de 1903.

${ }^{124}$ FERNANDEZ, Renato Lanna. A concepção de esporte em Antônio Prado Júnior: o amadorismo como princípio civilizatório e regenerador, op. cit., 2015. GAMBETA, Wilson. A bola rolou..., op. cit., 2015.
} 
BRUNO, Ernani Silva. História e tradições da cidade de São Paulo: burgo de estudantes (18281872). Rio de Janeiro: José Olímpio, 1954a.

BRUNO, Ernani Silva. História e tradições da cidade de São Paulo: metrópole do café (18721918). Rio de Janeiro: José Olímpio, 1954b.

BURKE, Peter \& PALLARES-BURKE, Maria Lúcia Garcia. Os ingleses. São Paulo: Contexto, 2016.

CANCLINI, Néstor García. Culturas híbridas: estratégias para entrar e sair da modernidade. São Paulo: Edusp, 1997.

FERNANDEZ, Renato Lanna. A concepção de esporte em Antônio Prado Júnior: o amadorismo como princípio civilizatório e regenerador. In: XXVIII SIMPÓSIO NACIONAL DE HISTÓRIA. Anais. Florianópolis: Anpuh, 2015. Disponível em: <http://www.snh2015.anpuh.org/resources/anais/39/1433603253_ARQUIVO_TEXTOPARAANPHU2015.pdf>. Acesso em: 5 abr. 2019.

FRANCO, Gustavo H. B. E LAGO, Luiz Aranha Corrêa do. O processo econômico/ a economia da Primeira República, 1889-1930. In: SCHWARCZ, Lília Moritz (coord.). História do Brasil nação (1808-2010), vol. 3: A abertura para o mundo (1889-1930). Rio de Janeiro: Objetiva, 2012, p. 173-238.

FREYRE, Gilberto. Ingleses no Brasil. $2^{\text {a }}$ edição. Rio de Janeiro: José Olympio/MEC, 1977.

GAMBETA, Wilson. A bola rolou: o velódromo paulista e os espetáculos de futebol. São Paulo: Editora Sesi, 2015.

GRAHAM, Richard. Grã-Bretanha e o início da modernização no Brasil. 1850-1914. São Paulo: Brasiliense, 1973.

GRANDI, Guilherme. Estado e capital ferroviário em São Paulo: a Companhia Paulista de Estradas de Ferro entre 1930 e 1961. Tese de doutorado, FFLCH/USP, São Paulo, 2013.

GUIMARÃES, Carlos Gabriel. A presença inglesa nas finanças e no comércio no Brasil imperial: os casos da Sociedade Bancária Mauá, MacGregor E Cia. (1854-1866) e da firma inglesa Samuel Phillips \& Cia. (1808-1840). São Paulo: Alameda Editorial, 2012.

HILSDORF, Maria Lúcia S. O Diário de São Paulo como fonte. In: VIDAL, Diana Gonçalves \& SOUZA, Maria Cecília Cortez de (org.). A memória e a sombra. A escola brasileira entre o Império e a República. Belo Horizonte: Autêntica, 1999, p. 21-31.

HOLT, Richard. Sport and the British: a modern history. Nova York: Oxford University Press, 1989.

JEHA, Silvana Cassab. Anphitheatrical Rio! Marítimos americanos na baía do Rio de Janeiro, século XIX. Almanack, n. 6, Guarulhos, 2013, p. 110-132. ISSN 2236-4633. Disponível em: <http://www.scielo.br/pdf/alm/n6/2236-4633-alm-06-00110. pdf>. Acesso em: 5 abr. 2019. DOI: http://dx.doi.org/10.1590/2236-463320130608.

LUCA, Tânia Regina de. História dos, nos e por meio dos periódicos. In: PINSKY, Carla Bassanezi (org.). Fontes históricas. São Paulo: Ed. Contexto, 2005, p. 111-153.

MAGALDI, Sábato \& VARGAS, Maria Thereza. Cem anos de teatro em São Paulo. São Paulo: Senac, 2000.

MANGAN, James A. Athleticism in the Victorian and Edwardian public school. Cambridge: University Press, 1981. 
MANGAN, James A. The games ethic and imperialism: aspects of the diffusion of an ideal. Nova York: Viking, 1986.

MARTINS, Ana Luiza E LUCA, Tania Regina de. Imprensa e cidade. São Paulo: Editora Unesp, 2006.

MELO, Victor Andrade de. Mulheres em movimento: a presença feminina nos primórdios do esporte na cidade do Rio de Janeiro (até 1910). Revista Brasileira de História, vol. 27, n. 54, São Paulo, dez. 2007, p. 127-152. ISSN 1806-9347. Disponível em: <http://www.scielo.br/pdf/rbh/v27n54/a08v2754.pdf>. Acesso em: 5 abr. 2019. DOI: http://dx.doi.org/10.1590/S0102-01882007000200008.

MELO, Victor Andrade de. Esporte e lazer: conceito - uma introdução histórica. Rio de Janeiro: Apicuri/Faperj, 2010.

MELO, Victor Andrade de. Educação do corpo - bailes no Rio de Janeiro do século XIX: o olhar de Paranhos. Educação e Pesquisa, vol. 40, n. 3, São Paulo, jul. 2014, p. 751-766. ISSN 1678-4634. Disponível em: <http://www.scielo.br/ pdf/ep/2014nahead/aop1410.pdf $>$. Acesso em: 5 abr. 2019. DOI: https://doi. org/10.1590/S1517-97022014005000004.

MELO, Victor Andrade de. A sociabilidade britânica no Rio de Janeiro do século XIX: os clubes de cricket. Almanack, n. 16, Guarulhos, ago. 2017a, p. 168-205. ISSN 2236-4633. Disponível em: <http://www.scielo.br/pdf/alm/ n16/2236-4633-alm-16-00168.pdf>. Acesso em: 5 abr. 2019. DOI: http://dx.doi. org/10.1590/2236-463320171604.

MELO, Victor Andrade de. Para inglês ver? Os clubes de cricket e a sociabilidade britânica em Recife (1865-1906). Territórios e Fronteiras, vol. 10, n. 1, Dourados, jan.-jul. 2017b, p. 161-178. ISSN 2175-0742. Disponível em: <http://ppghis.com/ territorios $\mathcal{E}$ fronteiras/index.php/v03n02/article/view/568>. Acesso em: 5 abr. 2019. DOI: http://dx.doi.org/10.22228/rt-f.v10i1.568.

MELO, Victor Andrade de $\mathcal{E}$ GONÇALVES, Michelle Carreirão. Antes do american way of life: experiências com o baseball no Rio de Janeiro e São Paulo da transição dos séculos XIX e XX. Revista de História da Unisinos, vol. 22, n. 3, São Leopoldo, 2018, p. 442-452. ISSN 2236-1782. Disponível em: <http://revistas.unisinos.br/ index.php/historia/article/view/htu.2018.223.09>. Acesso em: 5 abr. 2019. DOI: 10.4013/htu.2018.223.09.

MELO, Victor Andrade de $\mathcal{E}$ GONÇALVES, Michelle Carreirão. À sombra do futebol: experiências com o rugby nas duas primeiras décadas do século XX. Movimento, Porto Alegre, 2018. No prelo.

MELO, Victor Andrade de $\mathcal{E}$ PERES, Fábio de Faria. A gymnastica no tempo do Império. Rio de Janeiro: 7 Letras, 2014.

MELO, Victor Andrade de $\mathcal{E}$ SANTOS, Flávia da Cruz. Deslizando rumo ao progresso: a patinação em São Paulo (1877-1912). Movimento, vol. 23, n. 1, Porto Alegre, mar. 2017, p. 171-184. ISSN 1982-8918. Disponível em: <https://seer. ufrgs.br/Movimento/article/view/61350>. Acesso em: 5 abr. 2019. DOI: https:// doi.org/10.22456/1982-8918.61350. 
Victor Andrade Melo e Eduardo Souza Gomes Os britânicos e os clubes de cricketna São Paulo do século XIX (anos 1870-1890)

MELO, Victor Andrade de $\mathcal{E}$ SANTOS, Flávia da Cruz. Escola de virtudes: a dança na São Paulo do século XIX (décadas de 1830-1860). Educação e Realidade, vol. 43, n. 3, Porto Alegre, 2018, p. 1031-1054. ISSN 2175-6236. Disponível em: <https:// seer.ufrgs.br/educacaoerealidade/article/view/74388>. Acesso em: 5 abr. 2019. DOI: http://dx.doi.org/10.1590/2175-623674388.

MILLS, John. Charles Miller: o pai do futebol brasileiro. Rio de Janeiro: Panda Books, 2014. MONTEIRO, Arlete Assumpção. Os imigrantes ao longo dos trilhos da The São Paulo Railway. Raízes, n. 19, São Caetano do Sul, ano X, jul. 1999, p. 37-43.

ROCHA, Antônio Penalves. The Rio News de A. J. Lamoureux: um jornal abolicionista carioca de um norte-americano. Projeto História, n. 35, São Paulo, dez. 2007, p. 141-159. ISSN 0102-4442. Disponível em:<https://revistas.pucsp.br/index.php/ revph/article/view/2210>. Acesso em: 5 abr. 2019.

ROLNIK, Raquel. São Paulo, início da industrialização: o espaço é político. In: KOWARICK, L. (org.). As lutas sociais e a cidade. São Paulo: Paz e Terra / Unrisd, 1988, p. 207-245.

SAES, Flávio Azevedo Marques. Asferrovias deSão Paulo, 1870-1940. São Paulo:Hucitec, 1981.

SALIBA, Elias Thomé. Cultura/As apostas na República. In: SCHWARCZ, Lília Moritz (coord.). História do Brasil nação (1808-2010), vol. 3: A abertura para o mundo (1889-1930). Rio de Janeiro: Objetiva, 2012, p. 239-294.

SANTOS, Flávia da Cruz \& MELO, Victor Andrade de. Entre o rural e o urbano: as touradas na São Paulo do século XIX (1877-1889). Revista do IHGB, n. 463, Rio de Janeiro, abr./jun. 2014, p. 39-69. ISSN 0101-4366. Disponível em:<https://ihgb.org. $\mathrm{br} /$ revista-eletronica/artigos-463/item/108159-entre-o-rural-e-o-urbano-astouradas-na-sao-paulo-do-seculo-xix-1877-1889.html>. Acesso em: 5 abr. 2019.

SCHWARCZ, Lília Moritz. As marcas do período. In: Idem (coord.). História do Brasil nação (1808-2010), vol. 3: A abertura para o mundo (1889-1930). Rio de Janeiro: Objetiva, 2012, p. 19-34.

SCHWARCZ, Lília Moritz. População e sociedade. In: Idem (coord.). História do Brasil nação (1808-2010), vol. 3: A abertura para o mundo (1889-1930). Rio de Janeiro: Objetiva, 2012b, p. 35-84.

SILVA, Elisangela Maria. Práticas de produção e apropriação do espaço em São Paulo: a concessão de terras municipais através das cartas de datas (1850-1890). Dissertação de mestrado em Arquitetura e Urbanismo, Universidade de São Paulo, São Paulo, 2012.

SILVA, Gustavo Pereira da. A dinâmica do enriquecimento paulista no século XIX: das origens à diversificação do capital da família Lacerda Franco. Estudos Econô ${ }^{-}$ micos, vol. 45, n. 2, São Paulo, 2015, p. 347-376. ISSN 1980-5357. Disponível em: <http://www.scielo.br/pdf/ee/v45n2/0101-4161-ee-45-02-0347.pdf>. Acesso em: 5 abr. 2019. DOI: http://dx.doi.org/10.1590/0101-4161201545244gps.

SOARES, Luiz Carlos. A Albion revisitada. Rio de Janeiro: 7 Letras/Faperj, 2007.

SZMRECSÁNYI, Tamás. História econômica da cidade de São Paulo. Rio de Janeiro: Globo, 2004.

TELAROLLI JÚNIOR, Rodolfo. Imigração e epidemias no Estado de São Paulo. História, Ciências, Saúde - Manguinhos, vol. 3, n. 2, Rio de Janeiro, 1996, p. 265283. ISSN 1678-4758. Disponível em: <http://www.scielo.br/pdf/hcsm/v3n2/ v3n2a04.pdf>. Acesso em: 5 abr. 2019. DOI: http://dx.doi.org/10.1590/S010459701996000200004. 
THALASSA, Ângela. O Correio Paulistano: o primeiro diário de São Paulo e a cobertura da Semana de Arte Moderna - o jornal que não ladra, não cacareja e não morde. Dissertação de mestrado em Comunicação e Semiótica, Pontifícia Universidade Católica de São Paulo, São Paulo, 2007.

TOLEDO, Roberto Pompeu de. A capital da solidão: uma história de São Paulo das origens a 1900. Rio de Janeiro: Objetiva, 2003.

TOLEDO, Roberto Pompeu de. A capital da vertigem: uma história de São Paulo de 1900 a 1954. Rio de Janeiro: Objetiva, 2015.

VIEIRA, Marina Tucunduva Bittencourt Porto. Esporte, cidade e modernidade: Santos. In: MELO, Victor Andrade de (org.). Os sports e as cidades brasileiras: transição dos séculos XIX e XX. Rio de Janeiro: Apicuri, 2010, p. 71-95.

Recebido: 02/10/2017 - Aprovado: 25/03/2019 